\title{
Source of polynuclear aromatic hydrocarbons found in sediment in a region of expanding sugarcane cultivation of São Paulo State, Brazil
}

\author{
Glaucia Pantano $^{1}$ - Vitor C. Ferrizzi ${ }^{1} \cdot$ Márcia C. Bisinoti $^{1} \cdot$ Altair B. Moreira $^{1}$
}

Received: 1 June 2015 / Accepted: 30 November 2015 /Published online: 21 December 2015

(C) Springer-Verlag Berlin Heidelberg 2015

\begin{abstract}
Purpose Polycyclic aromatic hydrocarbons (PAHs) are unintentional products that are classified as persistent toxic substances. The goal of the present study was to generate data on the presence of 15 priority PAHs that are found in surface sediment and core sediment in the region of the Turvo/ Grande watershed, São Paulo State, Brazil, which is an area of expanding sugarcane cultivation, and to correlate these data with the sources of these PAHs and the guiding values for sediment quality analysis.

Materials and methods Surface sediments and sediment cores were sampled during the rainy and dry seasons in February and July 2010. The extraction of PAHs from sediments was performed using a Soxhlet extractor, and then the extract was cleaned according to the methods of the US EPA 3630C (US EPA 1996) using a silica gel column. Quantification was performed using high performance liquid chromatography with fluorescence detection.

Results and discussion The concentrations of all 15 PAHs decreased as the depth of the sediment core increased. Overall, the concentrations decreased along the sediment core; however, the RTURARG (region predominantly used for planting sugarcane and livestock) during the rainy season and the CAPRP sampling site (located at part of the Preto River
\end{abstract}

Responsible editor: Karl J. Rockne

Altair B. Moreira

altair@ibilce.unesp.br

1 Laboratório de Estudos em Ciências Ambientais, Instituto de Biociências, Letras e Ciências Exatas, UNESP, Univ Estadual Paulista, Campus São José do Rio Preto, Departamento de Química e Ciências Ambientais, R. Cristóvão Colombo 2265, 15054-000 São José do Rio Preto, SP, Brazil dam) during the dry season showed increased concentrations in the first few sediment fractions, and then the concentrations decreased. Higher concentrations were observed in urban locations, and the concentration of naphthalene was higher than the probable effect level (PEL) determined by the Canadian environmental agency. The obtained diagnostic ratios indicate that the sediment from areas with an abundance of sugarcane was a pyrolytic source of PAHs, which indicates a contribution from burning straw to the PAH concentrations in those areas. Conclusions For all sampling sites and all PAHs, we found a decreasing trend in PAH concentrations with increasing sediment core depth, and the locations, such as CAPRP, that experienced a higher level of human activity had the highest total concentrations of PAHs. These locations were the only areas in which the PAH naphthalene was found in higher concentrations than the PEL. The diagnostic ratios reveal that regions with sugarcane plantations had predominantly pyrolytic sources of PAHs, indicating the contribution of PAHs from sugarcane straw burning.

Keywords Diagnostic ratios $\cdot$ PEL $\cdot$ Polynuclear aromatic hydrocarbons $\cdot$ Sediment $\cdot$ TEL

\section{Introduction}

Polycyclic aromatic hydrocarbons (PAHs) are unintentional products that are considered as persistent toxic substances and are composed of two or more benzene rings fused in linear, angular, or clustered arrangements. They arise from natural and anthropogenic sources that can be classified as biogenic, pyrolytic, and petrogenic (Lopes and Andrade 1996; Lors et al. 2010). The latter two sources represent the highest contribution to PAH emissions and include internal combustion powered by petroleum engines, the use of 
incinerators and residential heaters, fires, the refining of fossil fuels, the processing of wood products, iron and steel production, and textile factories (Sho et al. 2004; Haritash and Kaushik 2009). PAHs are found in different concentrations in the atmosphere, water, soil, and sediment (Manoli et al. 2004; Almeida et al. 2007; Ströher et al. 2007; Cheng et al. 2013; El-Mufleh et al. 2013; Gebara et al. 2013; Shahsavari et al. 2013; Silva et al. 2013; Belin et al. 2014; Prokes et al. 2014; Zheng et al. 2014). Almeida et al. (2007) conducted an inventory of PAH emissions in Brazil that included the primary sources of the atmospheric emission of 16 PAHs that are considered priority substances by the US Environmental Protection Agency (US EPA). In this study was demonstrated that nearly all PAHs issued (94.8 \% or 7,346 t/year) are the result of combustion processes, with $83.8 \%$ of these emissions resulting from the burning of wood and $11.1 \%$ resulting from biomass burning.

PAHs may accumulate in sediments because they have low water solubility and a high octanol-water partition coefficient (Kow). Therefore, PAHs have a high affinity for sediment particles and adsorbent materials rich in organic matter, which leads to the accumulation of this class of contaminants through the deposition of particulate and solid materials in which PAHs are adsorbed (Chiou 2002; Karichkhoff 1981; Luthy et al. 1997). Thus, the assessment of the levels and distribution of PAHs in sediment may indicate the source and intensity of human activity because these compounds are associated with characteristic sources of pollution (Nishigima et al. 2001; Han et al. 2015).

The Turvo/Grande watershed is a region of expanding sugarcane cultivation and is located in the city of São José do Rio Preto, which is a large urban center. The primary sources of PAHs in this region are pyrolytic, particularly fossil fuel and biomass burning. This region is one of the leading producers of sugarcane in Brazil, and the burning of sugarcane straw is a common occurrence (Magalhães et al. 2007; Andrade et al. 2010; Cristale et al. 2012; Conab 2015). In this study, the northwest region of São Paulo was chosen to investigate the robust expansion of the sugarcane agribusiness industry.

To estimate the origins of PAHs, specific ratios of isomers have been widely used. The use of these ratios is based on the fact that PAH composition indicates characteristics corresponding to the source of emission. The phenanthrene/(anthracene + phenanthrene $)$, fluoranthene/(pyrene +

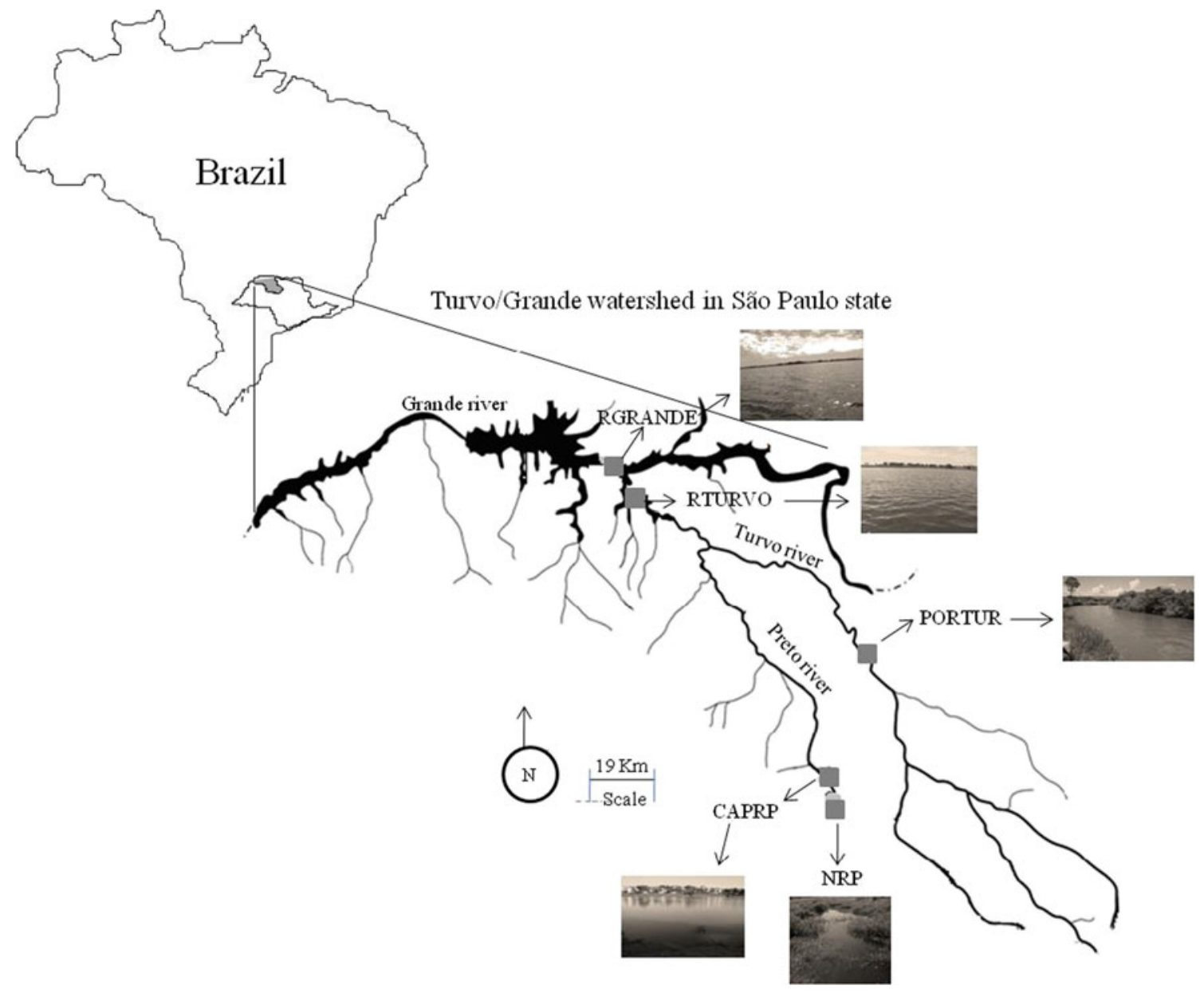

Fig. 1 Map of the locations of the sampling sites located at Turvo/Grande watershed 
fluoranthene), and chrysene/(chrysene+benzo [a] anthracene) ratios, among others, have been described and applied in several studies to estimate the origin of PAHs (Liu et al. 2000; Luo et al. 2008; Shen et al. 2009; Denis et al. 2012; Zhang et al. 2013).

In view of these findings, the aim of the present study was to generate new data on the prevalence of 15 priority PAHs (naphthalene, acenaphthene, fluorene, phenanthrene, anthracene, fluoranthene, pyrene, benzo[a]anthracene, chrysene, benzo[b]fluoranthene, benzo[k]fluoranthene, benzo[a]pyrene, dibenzo[ah]anthracene, benzo[ghi]perylene, and indeno[123cd]pyrene) in surface and core sediments from the region of study and to correlate these data with sources and the values used to guide sediment quality analysis.

\section{Materials and methods}

\subsection{Study area}

This study focused on sediments from the primary bodies of water of the Turvo/Grande watershed (the Preto Turvo and Grande Rivers), which is composed of 64 municipalities and has a drainage area of $15,974 \mathrm{~km}^{2}$. This region supports the food industry, metallurgy and jewelry production, sugar and alcohol production, the plastic and paper industries, and cardboard factories (CBH-TG-Turvo/ Grande Drainage Basin Committee 2010; Secretaria de Desenvolvimento e Palnejamento Social 2012).

The cultivation of sugarcane has expanded throughout Brazil, and the state of São Paulo leads sugarcane production in the country. The region of Sao Jose do Rio Preto is one of the largest producers in São Paulo State, which is responsible for $51.7 \%$ of the total production in the Brazil (Conab 2015). The region of Sao Jose do Rio Preto is served by three high-traffic roads: the Washington Luis Highway (SP-310), the Transbrasiliana Highway (BR153), and the Highway Assis Chateaubriand (SP-425).

The Turvo/Grande watershed is situated at an altitude of approximately $500 \mathrm{~m}$, and $78 \%$ of its territory is undulating topography, with only 19 and $3 \%$ corresponding to flat or mountainous regions, respectively. Red argilossolo, yellow soil and oxisol soil are prevalent in the region. Much of the watershed is at risk of erosion (IBGE 2015).

\subsection{Sample collection sites}

Five sampling sites were selected on the water bodies (the Preto, Turvo, and Grande Rivers) of the Turvo/Grande watershed (Fig. 1).

The NRP sampling site (at the source of the Preto River, considered the reference area, S20 $55^{\prime} 11.3^{\prime \prime}$; W049 $17^{\prime}$ $\left.59.9^{\prime \prime}\right)$ is located in a rural area, close to sugarcane plantation areas. Although this location is adjacent to sugarcane and orange plantations, it is less subject to anthropogenic effects. Sediment at this site has an organic matter content of $13.5 \%$, and its particle sizes are predominantly sandy at $44.5 \%$. The CAPRP site (S20 48'29.2"; W049 $\left.22^{\prime} 24.1^{\prime \prime}\right)$ is part of the Preto River dam, located in the urban area of São José do Rio Preto, which is close to the public water supply. The content of organic matter in the sediment ranges from 4.9 to $17.1 \%$, and $57.7 \%$ is sand (Campanha et al. 2014). There is a large amount of urban vehicular traffic near the municipal dam.

The PORTUR (S20 44'31.8"; W049 06'11.4") and RTURARG (S19 58'09.8'; W049'53'37.1") sampling sites are on the Turvo River, with PORTUR located on the bridge that connects the city of São José do Rio Preto to Olímpia (PORTUR), which is a receiving area of the organic loads of the Catanduva and São Domingos Rivers, located in a sugarcane crop area. The latter (RTURARG) is located in a region predominantly used for planting sugarcane and livestock. The PORTUR site has predominantly sandy sediments, at $97.1 \%$, and an organic matter content of $0.9 \%$, and the RTURARG site has $64.9 \%$ sandy sediment and an organic matter content ranging between 4.9 and $19.8 \%$ (Campanha et al. 2014). The

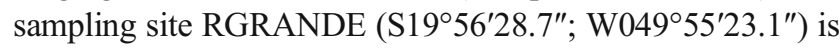
located in the Grande River in a hydroelectric impoundment area that receives the pollution load of the watershed and hosts some sugarcane plantations. This site has $60.9 \%$ sandy sediment and an organic matter content between 5.8 and $14.6 \%$ (Campanha et al. 2014).

\subsection{Sediment sampling}

Sediments were sampled in two seasons, once in February 2010 (during the rainy season in which a cumulative rainfall of $210.7 \mathrm{~mm}$ was recorded in the region of São José do Rio Preto city) and once in July 2010 (during the dry season in which a cumulative rainfall of $5.5 \mathrm{~mm}$ was recorded in the region of São José do Rio Preto city). The sampling procedures and the preservation of sediment samples were performed following the recommendations proposed by the NBR 9898 (ABNT 1987). Samples of surface sediment were collected with the aid of a Van Veen dredger, and the samples of core sediment were collected with the aid of a Kajak-type core sampler containing an acrylic tube with a diameter of $10 \mathrm{~cm}$ and a depth of up to $60 \mathrm{~cm}$. Three sediment samples were collected at each sampling site. The cores were sliced into $3-\mathrm{cm}$-thick layers and were stored at $-18{ }^{\circ} \mathrm{C}$ until analysis. Three samples were collected for each sampling site, and composite samples were prepared for surface sediment and for sediment core. The $\mathrm{pH}$ values for the five sampling sites ranged between 5.8 and 7.1, with the lowest value 
obtained at the RGRANDE site, and the highest at CAPRP (Campanha et al. 2014).

\subsection{Chemical reagents, extraction, and instrumental analyses}

For sediment PAH extraction and clean-up, $n$-hexane, acetone Pestanal ${ }^{\circledR}$ grade, anhydrous sodium sulfate (ACS reagent, $99 \%$ purity), iso-octane, dichloromethane Chromasolv $^{\circledR}$ grade, methanol (puriss pa, ACS), and silica gel grade 923 were used. For the identification and quantification of PAHs, a kit from Sigma Aldrich containing 16 PAHs (EPA 610-N PAH Kit) was used. Stock solutions were prepared in acetonitrile from which calibration standards were prepared by serial dilutions.

The extraction of PAH sediment was performed according to method $3540 \mathrm{C}$, recommended by the US Environmental Protection Agency (US EPA 1996a), using a
Soxhlet extractor assembly. Approximately $2 \mathrm{~g}$ of dry sediment was subjected to extraction for $16 \mathrm{~h}$ following the addition of $150 \mathrm{~mL}$ of a acetone and hexane $(1: 1, v / v)$ mixture. A control was prepared in the same manner but without sediment. After an additional $20 \mathrm{~mL}$ of isooctane was added, the extract was concentrated in a rotary evaporator to reduce it to approximately $2 \mathrm{~mL}$. Subsequently, the extract was cleaned using a silica gel column (10 g) according to method $3630 \mathrm{C}$ of the US EPA (US EPA 1996b). The column was first rinsed with $40 \mathrm{~mL}$ hexane solvent to remove non-PAH impurities, such as aliphatic hydrocarbons. Then, the column was rinsed with $20 \mathrm{~mL}$ of a methylene chloride and $n$-hexane $(2: 3, v / v)$ mixture; this extract was concentrated in a rotary evaporator. After an additional $20 \mathrm{~mL}$ of acetonitrile was added, this extract containing the PAHs was collected and concentrated to approximately $2 \mathrm{~mL}$ using a rotary evaporator. To ensure quality control, the method was verified by extracting a
Fig. 2 Concentrations $\left(\mathrm{ng} \mathrm{g}^{-1}\right)$ of naphthalene, acenaphthene, fluorene, phenanthrene, anthracene, and fluoranthene in sediment cores collected in the Preto river (CAPRP), the Turvo river (RTURARG), and the Grande river (RGRANDE) in February 2010

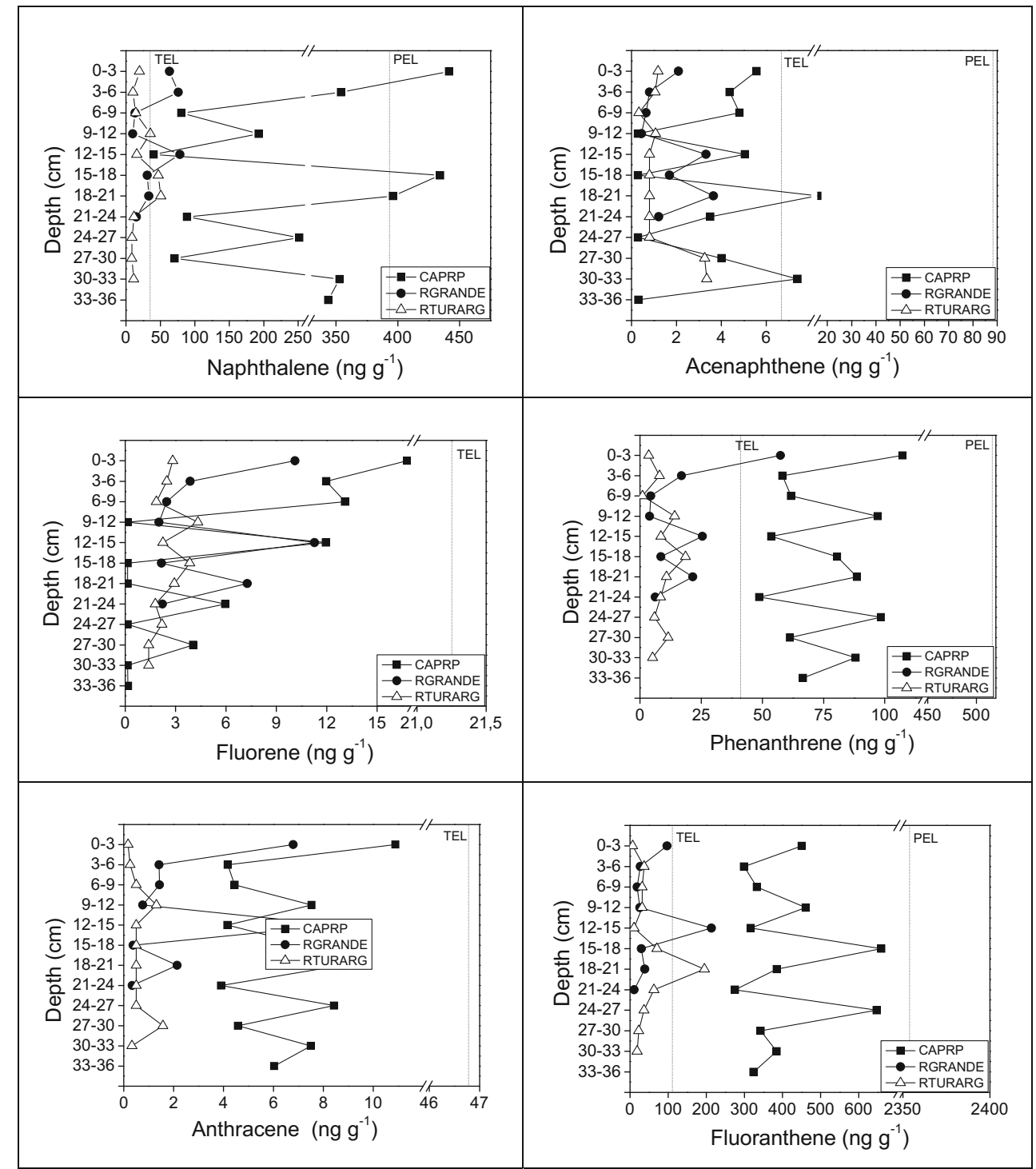


Fig. 3 Concentrations $\left(\mathrm{ng} \mathrm{g}^{-1}\right)$ of pyrene, benzo[a]anthracene, benzo[b]fluoranthene, benzo[k]fluoranthene, and benzo[ghi]perylene in sediment cores collected in the Preto river (CAPRP), the Turvo river (RTURARG), and the Grande river (RGRANDE) in February 2010

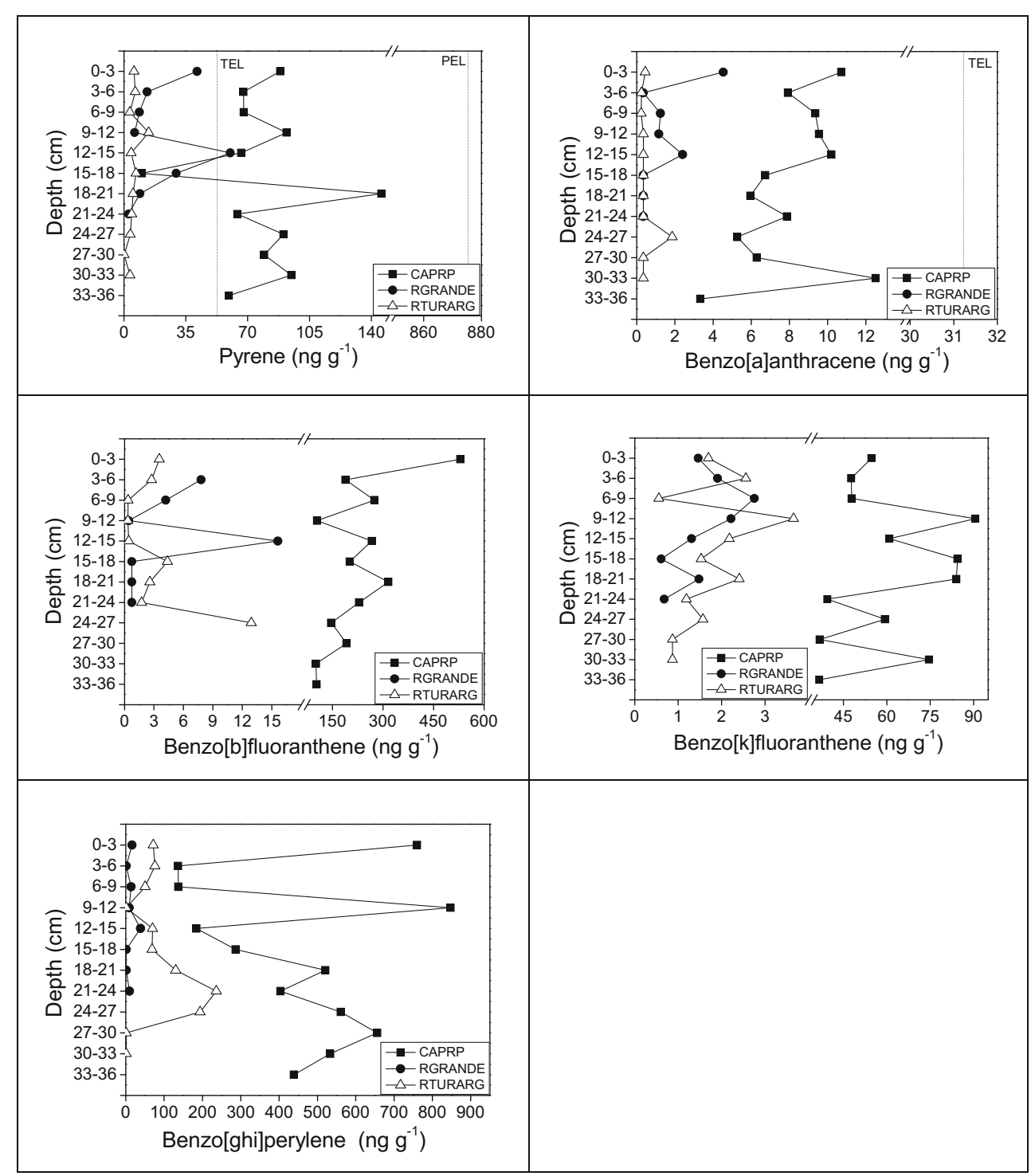

certified reference material (SRM 1944). The recoveries of the certified material ranged from 68.8 to $101.6 \%$, with a standard deviation of less than $10 \%$.

The PAHs were identified and quantified using highperformance liquid chromatography (Shimadzu Prominence HPLC system, manufactured in Kyoto, Japan) with fluorescence detection (HPLC-F). Quantification of the analytes was performed by an external standard method using a solution prepared of a mixture of 15 individual PAHs (Sigma Aldrich and Fluka) of interest. A ZORBAX Eclipse PAH column (Agilent; $4.6 \times 250 \mathrm{~mm}$ internal diameter and $5 \mathrm{~mm}$ particle size) was used. The injection volume was $20.0 \mu \mathrm{L}$, the flow rate was $1.3 \mathrm{~mL} \mathrm{~min}^{-1}$, and the temperature of the column was $25.0 \pm 0.1{ }^{\circ} \mathrm{C}$. The mobile phase was acetonitrile/water in gradient elution mode: $60 \%$ acetonitrile for $9 \mathrm{~min}$, followed by a linear increase until $100 \%$ acetonitrile was achieved (18 min), and then the $100 \%$ condition was maintained for $15 \mathrm{~min}$. The fluorescence detector was operated with a $220 \mathrm{~nm}$ excitation wavelength $\left(\lambda_{\text {ex }}\right)$ and a $398 \mathrm{~nm}$ emission wavelength $\left(\lambda_{\mathrm{em}}\right)$. However, indeno[1,2,3-cd]pyrene was analyzed at $300\left(\lambda_{\text {ex }}\right)$ and $498 \mathrm{~nm}\left(\lambda_{\text {em }}\right)$.

\subsection{Diagnostic ratios for the identification of PAH sources}

To evaluate the potential sources of PAHs found in the aquatic environments studied, we used the ratios of $\mathrm{PAH}$ isomer concentrations reported by previous studies. Phenanthrene/anthracene (Phe/Ant), anthracene/(anthracene + phenanthrene), fluoranthene/(fluoranthene + pyrene), and low-molecular weight/high molecular weight ratios were used to determine the PAH sources (Budzinski et al. 1997; Liu et al. 2000; Soclo et al. 2000; Doong and Linn 2004; Luo et al. 2008; Shen et al. 2009; Denis et al. 2012; Zhang et al. 2013). 
Fig. 4 Concentrations $\left(\mathrm{ng} \mathrm{g}^{-1}\right)$ of naphthalene, acenaphthene, fluorene, phenanthrene, anthracene, and fluoranthene in sediment cores collected in the Preto river (CAPRP), the Turvo river (RTURARG), and the Grande river (RGRANDE) in July 2010

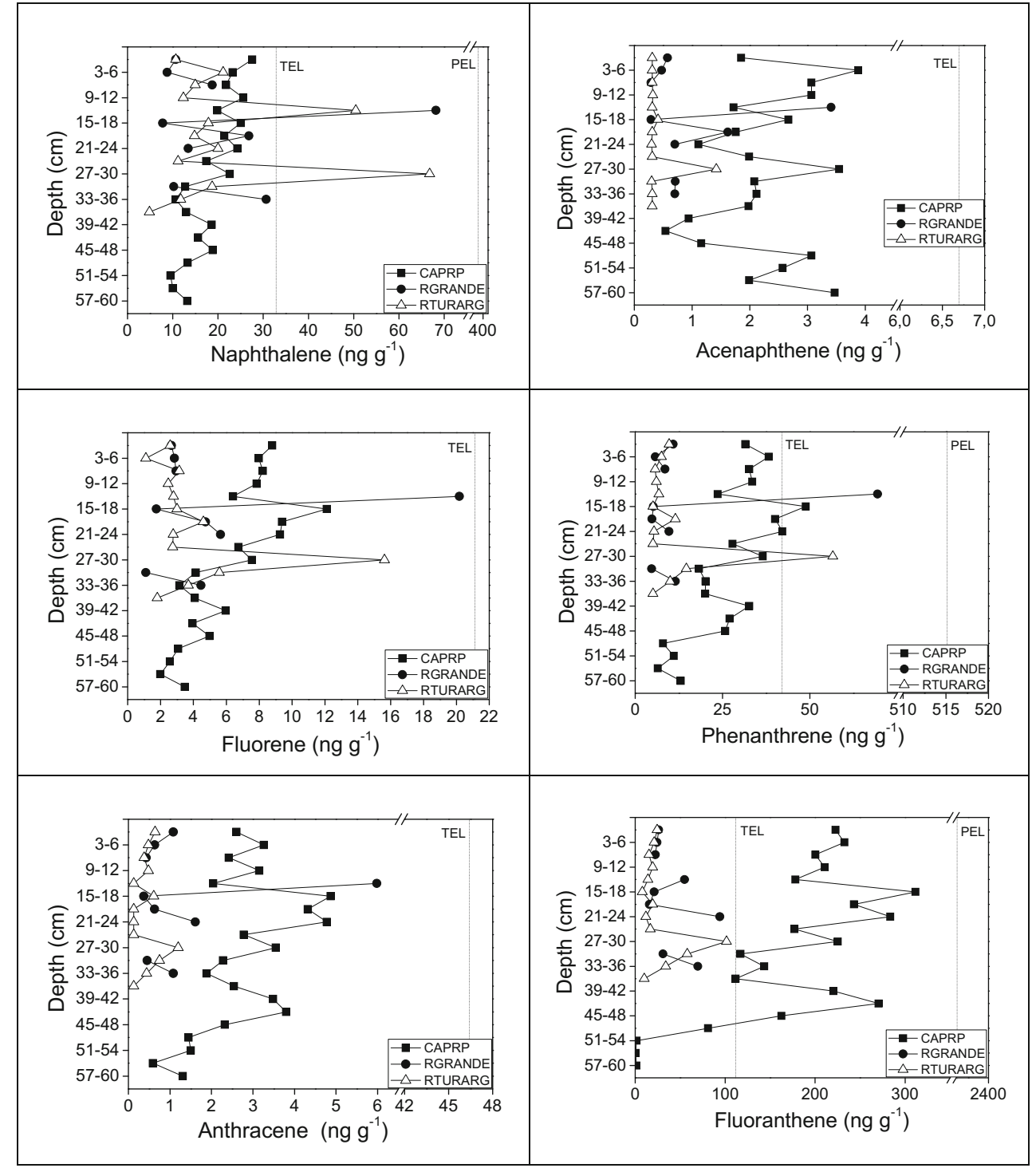

\section{Results and discussion}

\subsection{Evaluation of the analytical method}

The instrumental stability was checked daily using PAH standards, and the measured deviation was less than $15 \%$. The correlation coefficients obtained from calibration curves are consistent with the values suggested by INMETRO $(>0.9)$ and ANVISA ( $>0.99$; ANVISA 2003; INMETRO 2003). The detection limit for all PAHs varied from 0.26 to $4.8 \mathrm{ng} \mathrm{g}^{-1}$ dry sediment sample. All experiments were performed in triplicate with less than $8 \%$ error. The accuracy of each method was verified by a certified reference material (SEM 1944) with recoveries range from 68.8 to $101.6 \%$. Naphthalene and pyrene presented the worst and the best recovery, respectively. These recovery values are in agreement with other reported studies, with recoveries ranging from 64 to $126 \%$ (Zhang et al. 2012; Silva et al. 2013).

\subsection{Polycyclic aromatic hydrocarbons in sediment cores}

There is no Brazilian law that determines the maximum values of PAHs allowed in aquatic sediments that are not subject to dredging. Therefore, this study compared the PAH concentrations found in sediments with values of Quality Guide Sediments (SQVG) determined for the protection of Canadian aquatic life.

Figures 2, 3, 4, and 5 illustrate the concentrations of PAHs in sediment cores collected during the rainy and dry seasons. Based on these results, some PAH concentrations along the sampled rivers exceeded the threshold effect level (TEL) and the probable effect level (PEL) established by the Canadian environmental agency (CCME 2002).

The CAPRP site during the rainy season had naphthalene concentrations (Fig. 2) in some sections that were higher than the PEL value (391 $\mathrm{ng} \mathrm{g}^{-1}$ ) and acenaphthene concentrations 
Fig. 5 Concentrations $\left(\mathrm{ng} \mathrm{g}^{-1}\right)$ of pyrene, benzo[a]anthracene, benzo[b]fluoranthene, benzo[k]fluoranthene, and benzo[ghi]perylene in sediment cores collected in the Preto river (CAPRP), the Turvo river (RTURARG), and the Grande river (RGRANDE) in July 2010

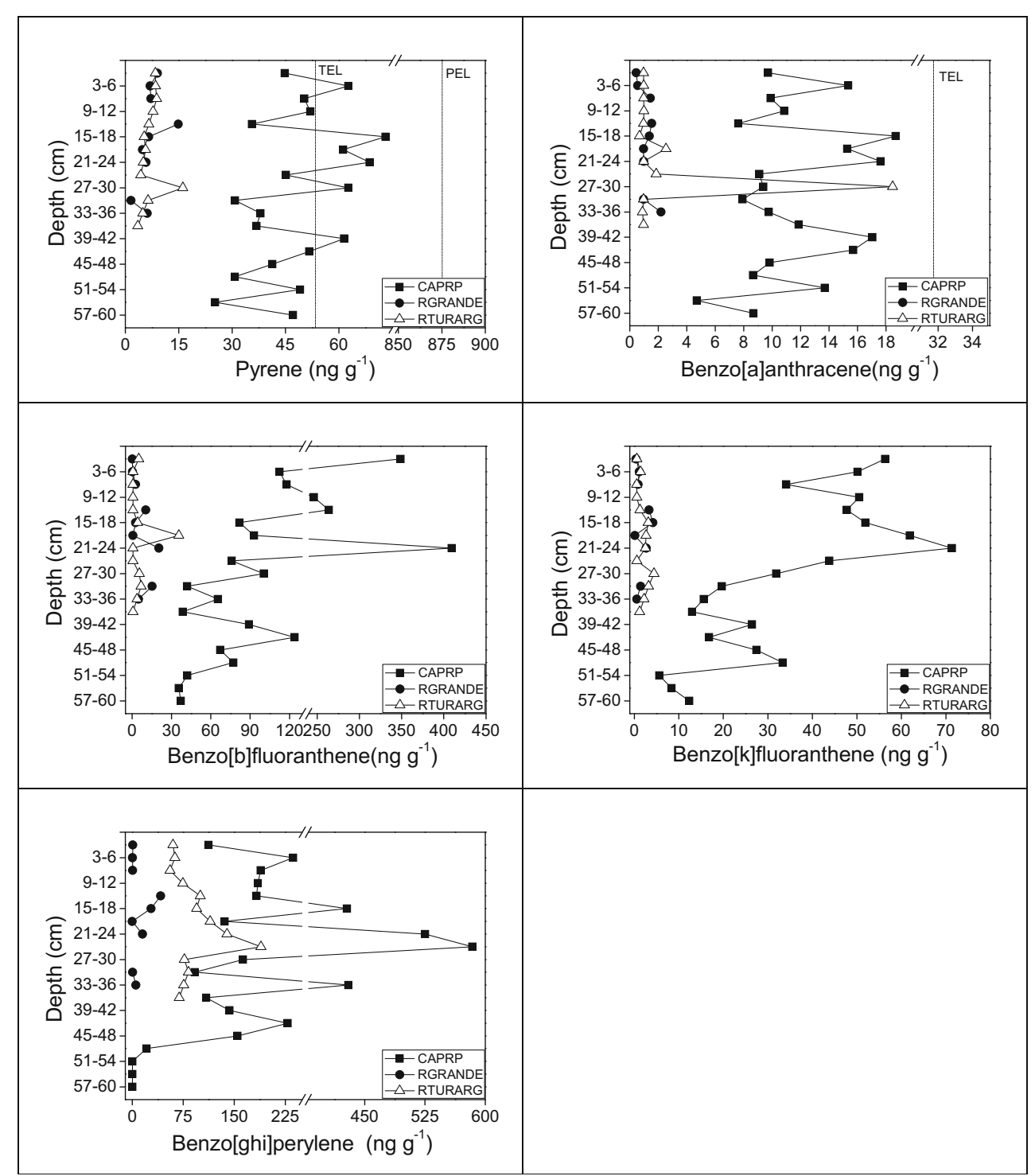

in deeper sediment layers that exceeded the TEL values (6.71 ng g $\left.{ }^{-1}\right)$. Concentrations of phenanthrene, fluoranthene (Fig. 2), and pyrene (Fig. 3) that were higher than the TEL value $\left(41.9,111\right.$, and $53 \mathrm{ng} \mathrm{g}^{-1}$, respectively) were found throughout the sediment core (CCME 2002).

During the dry season, the concentration of phenanthrene (Fig. 4) in two sediment samples was higher than the TEL value (41.9 $\mathrm{ng} \mathrm{g}^{-1}$ ), but the concentrations of fluoranthene and pyrene (Figs. 4 and 5, respectively) were higher than the TEL values (111 and $53 \mathrm{ng} \mathrm{g}^{-1}$, respectively) throughout the sediment core (CCME 2002).

At the RGRANDE site during the rainy season, the naphthalene concentrations (Fig. 2) in some sections were higher than the TEL value (34.6 $\mathrm{ng} \mathrm{g}^{-1}$ ), while for phenanthrene (Fig. 2), only the sediment surface concentration value exceeded the TEL value (111 $\left.\mathrm{ng} \mathrm{g}^{-1}\right)$. For fluoranthene (Fig. 2) and pyrene (Fig. 3), the concentration at $12-15 \mathrm{~cm}$ was higher than the TEL value (111 and $53 \mathrm{ng} \mathrm{g}^{-1}$, respectively). In the dry season, only the naphthalene and phenanthrene concentrations (Fig. 4) in the section 12$15 \mathrm{~cm}$ deep (68.16 and $69.38 \mathrm{ng} \mathrm{g}^{-1}$, respectively) were higher than the TEL values (34.6 and $41.9 \mathrm{ng} \mathrm{g}^{-1}$, respectively; CCME 2002).

At RTURARG in the rainy season, the naphthalene (Fig. 2) concentration in some sediment sections was higher than the TEL value (34.6 $\mathrm{ng} \mathrm{g}^{-1}$ ). In the dry season, concentrations of naphthalene and phenanthrene were higher than the TEL value (Fig. 4).

Figure 6 illustrates the profile graphs of the total concentrations of PAHs ( $\mathrm{PAH})$ in sediment core samples. The TEL value for total PAH concentrations in sediment cores is $264.1 \mathrm{ng} \mathrm{g}^{-1}$, and CAPRP generally had total PAH concentrations above the TEL value throughout the cores from the rainy and dry seasons. At RGRANDE, the total PAH concentrations ranged from 35-380 and 34-226 $\mathrm{ng} \mathrm{g}^{-1}$ for the periods of February and July, respectively, and in some sediment 
Fig. 6 Total concentrations ( PAH) $\left(\mathrm{ng} \mathrm{g}^{-1}\right)$ in sediment cores collected at CAPRP, RGRANDE, and RTURARG in February 2010 and July 2010

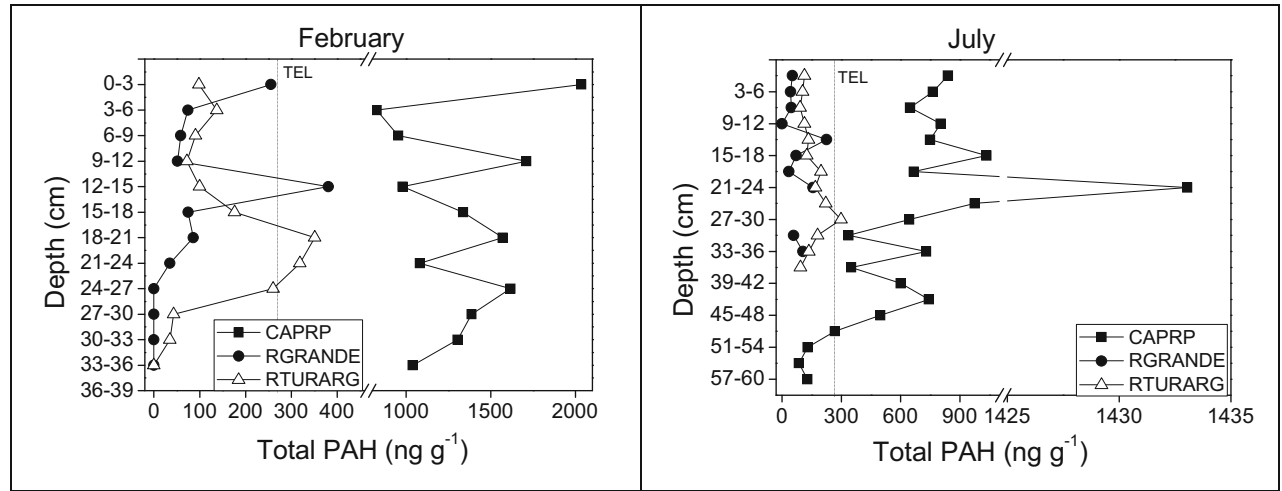

sections, the total concentrations were higher than the TEL value only during the rainy season. At RTURARG, the total concentration of PAHs along the sediment core ranged from 35-351 and from 92-297 $\mathrm{ng} \mathrm{g}^{-1}$ for February and July, respectively, and was higher than the TEL value in only a few layers of sediment.

The total concentrations of PAHs along the sediment cores behaved similarly for all sampling sites. Overall, there was a reduction in the concentrations along the core, but at RTURARG during the rainy season and at CAPRP during the dry season increased concentrations were observed in the first few fractions of sediment, which subsequently decreased. This increase in the concentrations of PAHs for the first few inches of sediment core and the subsequent decrease has been reported in the literature (Fukushima et al. 2012).

The decrease in the total concentration of PAHs in sediment cores, especially at CAPRP, shows that beginning at a certain time, this aquatic body has suffered from PAH emissions originating from anthropogenic sources. This site is part of the public water supply for the city of SJRP (municipal dam of São José do Rio Preto) and is located in an area of heavy vehicle traffic. In addition, several automobile repair shops and car washes surround the reservoir, which serve as diffuse sources of contamination via the supply of petroleum products. Urban runoff can also be considered a source of contamination of the municipal dam. The central areas of SJRP have few local surface water drainage sites and the dam is located at a low elevation; thus, the reservoir receives floodwaters during periods of intense precipitation.

The total concentrations of the 15 PAHs found in the sediment followed the order of CAPRP $>$ RTURARG $>$ RGRANDE, which is expected and justified by the influences of the major sources of contribution to this aquatic body. The site with the highest concentration is in a region with high vehicle traffic that is prone to contamination by runoff and atmospheric deposition. The location with the secondhighest concentration is an area of intense sugarcane cultivation that also receives PAHs from the burning of sugarcane straw, an influence described in previous studies (Magalhães et al. 2007; Andrade et al. 2010; Cristale et al. 2012).
The total concentration of PAHs found in sediment cores in this study agrees with previous studies. A study of the Mundaú-Manguaba lagoon estuarine system in Alagoas, which is in a region affected by sugarcane monoculture practices and urbanization, found total concentrations of $16 \mathrm{PAHs}$ ranging from 29.2 to $222.7 \mathrm{ng} \mathrm{g}^{-1}$ at the Manguaba Lagoon and from 41.1 to $100.9 \mathrm{ng} \mathrm{g}^{-1}$ at the Mundaú Lagoon. The total concentration of PAHs in sediment cores from the Mundaú River ranged from 86.0 to $208.4 \mathrm{ng} \mathrm{g}^{-1}$ (Silva et al. 2013). Another study performed in 2012 at four lakes in Japan found total concentrations of PAHs in sediment cores ranging from 50 to 3,000 $\mathrm{ng} \mathrm{g}^{-1}$, depending on the lake studied. Each lake is influenced by different types of anthropogenic activities. It was concluded that the PAHs arose from pyrogenic sources, and the quantity was proportional to the population density (Fukushima et al. 2012).

\subsection{Polycyclic aromatic hydrocarbons in surface sediment samples}

Table 1 shows the PAH values determined at different locations of the Preto, Turvo and Grande Rivers in surface sediment samples. It appears that at CAPRP, the collection performed during February 2010 contained concentrations of naphthalene (442 $\mathrm{ng} \mathrm{g}^{-1}$ ) higher than the PEL value (391 $\mathrm{ng} \mathrm{g}^{-1}$ ), while concentrations of phenanthrene, fluoranthene, and pyrene (107, 450, and $88.4 \mathrm{ng} \mathrm{g}^{-1}$, respectively) were higher than the respective TEL values $(41.9,53$, and $111 \mathrm{ng} \mathrm{g}^{-1}$, respectively). In the collection performed during July 2010 at the same sample site, the fluoranthene concentration $\left(223 \mathrm{ng} \mathrm{g}^{-1}\right)$ was higher than the TEL value set by the Canadian environmental agency.

The collection at the RGRANDE site in February 2010 also contained concentrations of naphthalene and phenanthrene PAHs (63.3 and $57.4 \mathrm{ng} \mathrm{g}^{-1}$, respectively) higher than the TEL values (34.6 and $41.9 \mathrm{ng} \mathrm{g}^{-1}$, respectively). The other sampling sites had PAH concentrations below the TEL or PEL values.

At the RTURARG sampling site, which is typically sandy and has a low organic matter content (4.9-19.8\%), the 
Table 1 PAH values in surface sediment samples from NRP, CAPRP, PORTUR, RTURARG, and RGRANDE collected in February and July 2010

\begin{tabular}{|c|c|c|c|c|c|c|c|c|c|c|}
\hline PAHs & $\begin{array}{l}\text { NRP } \\
\text { Feb. } 2010\end{array}$ & $\begin{array}{l}\text { NRP } \\
\text { July } 2010\end{array}$ & $\begin{array}{l}\text { CAPRP } \\
\text { Feb. } 2010\end{array}$ & $\begin{array}{l}\text { CAPRP } \\
\text { July } 2010\end{array}$ & $\begin{array}{l}\text { PORTUR } \\
\text { Feb. } 2010\end{array}$ & $\begin{array}{l}\text { PORTUR } \\
\text { July } 2010\end{array}$ & $\begin{array}{l}\text { RTURARG } \\
\text { Feb. } 2010\end{array}$ & $\begin{array}{l}\text { RTURARG } \\
\text { July } 2010\end{array}$ & $\begin{array}{l}\text { RGRANDE } \\
\text { Feb. } 2010\end{array}$ & $\begin{array}{l}\text { RGRANDE } \\
\text { July } 2010\end{array}$ \\
\hline \multicolumn{11}{|l|}{ Concentration (ng $\mathrm{g}^{-1}$ ) } \\
\hline Naphthalene & 14.3 & 8.0 & 27.6 & 441.5 & 1.9 & 1.3 & 10.7 & 19.6 & 63.2 & 10.7 \\
\hline Acenaphthene & 1.0 & 0.5 & 1.7 & 5.5 & 1.7 & 1.2 & 0.3 & 1.2 & 2.1 & 0.6 \\
\hline Fluorene & 3.2 & 1.8 & 8.8 & 16.8 & 2.1 & 1.4 & 2.6 & 2.8 & 10.1 & 2.7 \\
\hline Phenanthrene & 4.6 & 2.6 & 31.5 & 107.2 & 4.6 & 3.2 & 9.7 & 3.6 & 57.4 & 11.0 \\
\hline Anthracene & 0.3 & 0.1 & 2.6 & 11.0 & 0.5 & 0.3 & 0.6 & 0.2 & 6.8 & 1.1 \\
\hline Fluoranthene & 10.1 & 5.6 & 222.7 & 450.6 & 13.2 & 9.2 & 24.4 & 6.9 & 97.0 & 26.1 \\
\hline Pyrene & 4.4 & 2.4 & 44.8 & 88.4 & 0.8 & 0.5 & 8.5 & 5.6 & 41.4 & 9.0 \\
\hline Benzo[a]anthracene & 0.4 & 0.2 & 9.7 & 10.7 & 1.4 & 1.0 & 1.0 & 0.4 & 4.5 & 0.5 \\
\hline Chrysene & n.d & n.d & n.d & n.d & n.d & n.d & n.d & n.d & n.d & n.d \\
\hline $\begin{array}{l}\text { Benzo[b]fluorant } \\
\text { hene }\end{array}$ & 8.7 & 4.8 & 348.8 & 530.0 & 6.9 & 4.8 & 5.1 & 3.5 & 18.2 & 0.3 \\
\hline $\begin{array}{l}\text { Benzo[k]fluorant } \\
\text { hene }\end{array}$ & 0.5 & 0.3 & 56.3 & 54.7 & 1.1 & 0.8 & 0.6 & 1.7 & 1.5 & 0.4 \\
\hline Benzo[a]pyrene & n.d & n.d & n.d & n.d & n.d & n.d & n.d & n.d & n.d & n.d \\
\hline $\begin{array}{l}\text { Dibenzo[ah]anthr- } \\
\text { acene }\end{array}$ & n.d & n.d & n.d & n.d & n.d & n.d & n.d & n.d & n.d & n.d \\
\hline Benzo[ghi]perylene & 19.1 & 10.6 & 112.2 & 759.6 & 15.0 & 10.6 & 60.1 & 72.1 & 16.4 & 1.0 \\
\hline $\begin{array}{l}\text { Indeno[123- } \\
\text { cd]pyrene }\end{array}$ & n.d & n.d & n.d & n.d & n.d & n.d & n.d & n.d & n.d & n.d \\
\hline $\mathrm{PAH}$ & 67.0 & 37.0 & 867.0 & 2476.0 & 49.0 & 34.0 & 124.0 & 118.0 & 319.0 & 63.0 \\
\hline
\end{tabular}

n.d. not detected

concentrations of all PAHs studied were lower than the TEL and PEL values set by the Canadian environmental agency (Campanha et al. 2014)

Although concentrations of some PAHs were found that were higher than the established TEL or PEL values, the individual values and their sums in surface sediments were generally in agreement with data from previous studies (Fernandes et al. 1997; Meniconi et al. 2002; Doong and Linn 2004; Venturini and Tommasi 2004; Medeiros et al. 2005; Maioli et al. 2010; Lin et al. 2013). A study conducted in the Mundaú-Manguaba lagoon estuarine system in Alagoas found total concentrations of 16 PAHs in surface sediment ranging from 2.9 to $84 \mathrm{ng} \mathrm{g}^{-1}$ in the Manguaba Lagoon and from 32.9 to $231.3 \mathrm{~g} \mathrm{ng}^{-1}$ in the Mundaú Lagoon (Maioli et al. 2010). In the Patos Lagoon, PAH concentrations ranged from 37.7 to 11 , $779.9 \mathrm{ng} \mathrm{g}^{-1}$; in Guanabara Bay, the concentrations ranged from 91 to $8,035 \mathrm{ng} \mathrm{g}^{-1}$, and in the Bay of All Saints, the concentrations ranged from 8 to $4,163 \mathrm{ng} \mathrm{g}^{-1}$ (Meniconi et al. 2002; Venturini and Tommasi 2004; Medeiros et al. 2005). A study of the sediment of the DMF reservoir in China found total concentrations of 16 PAHs ranging from 323 to $912 \mathrm{ng} \mathrm{g}^{-1}$, with the highest concentrations found for phenanthrene, fluoranthene, pyrene, fluorene, anthracene, and benzo[a]anthracene PAHs in decreasing order. In the Seine River in France,
PAH concentrations were found to range from 4 to $36 \mathrm{ng} \mathrm{g}^{-1}$, and at the Gao Ping River in Taiwan, concentrations ranged from 8 to $356 \mathrm{ng} \mathrm{g}^{-1}$ (Doong and Linn 2004).

When PAH values were compared between periods of dry and rainy seasons, the concentrations of PAHs were found to be higher during the rainy season at all sampling sites. The heterogeneity of sediments may be one of the factors responsible for this finding. This finding is also in agreement with data from previous studies, such as a study of sediment from Taihu Lake, China in which the total concentration of 15 PAHs in the lake during the rainy season ranged from 255.07 (dry weight) to $1,059.39 \mathrm{ng} \mathrm{g}^{-1} \mathrm{dw}$ and in the dry season, ranged from 208.94 to $1,002.78 \mathrm{ng} \mathrm{g}^{-1} \mathrm{dw}$. (Zhang et al. 2012).

\subsection{Use of diagnostic ratios of to identify sources of PAHs}

Several authors have used phenanthrene/anthracene (Phe/Ant) and anthracene/(anthracene+ phenanthrene) $\mathrm{Ant} /(\mathrm{Ant}+\mathrm{Phe})$ ratios to indicate whether the origins of hydrocarbons are pyrolytic or petrogenic (Budzinski et al. 1997; Yunker et al. 1999; Gogou et al. 2000).

Petroleum generally contains more phenanthrene than anthracene; therefore, higher values of the Phe/Ant ratio are found when the sources of PAH are primarily 
petrogenic, and fewer cases are found when the sources are pyrolytic. According to Budzinski et al. (1997), sediments with Phe/Ant ratios greater than 10 are primarily contaminated by petrogenic PAHs, and those with Phe/ Ant ratios less than 10 are primarily contaminated by pyrolytic PAHs (Budzinski et al. 1997). Flt/(Flt+Py) ratios higher than 0.5 are characteristic of wood, coal, and grass combustion, ratios less than 0.4 are characteristic of petroleum pollution, and Flt/(Flt $+\mathrm{Py})$ ratios between 0.4 and 0.5 are more related to liquid fossil fuel combustion, such as in vehicles and crude oil (Doong and Linn 2004). Pyroltic contamination is characterized by highmolecular weight (HMW), and petrogenic contamination is characterized by low molecular weight (LMW) PAHs; thus, LMW/HMW ratios lower than 1 indicate pyrolytic contamination (Soclo et al. 2000).

Table 2 shows the values of these ratios obtained for surface sediments from the different sampling sites. Taking the results from the NRP site as an example, the Phe/ Ant, Ant/(Ant+Phe), and LMW/HMW diagnostic ratios indicate predominantly petrogenic sources. In this region, PAHs of petrogenic origin may be attributable to oil products from local contamination events. The Flt/(Flt+Py) ratio indicated the presence of PAHs from pyrolytic origins, such as coal combustion.

At the CAPRP site in February 2010, the Phe/Ant, Ant/ (Ant+Phe), Flt/(Flt+Py), and LMW/HMW ratios indicated the presence of PAHs from pyrolytic origins, confirming the predominance of PAHs with four to five rings. The burning of sugarcane straw can contribute to the introduction of these PAHs; however, their main source is the combustion of fossil fuels because there is considerable vehicle traffic near the dam. In July 2010, the Phe/Ant and Ant/(Ant+Phe) ratios indicated contributions from petrogenic sources; however, the Flt/(Flt+Py) and LMW/HMW ratios indicated the presence of PAHs from pyrolytic origins. These PAHs may be derived from the dumping of fossil fuel products from machine shops and washer jets located around the dam.

In both samples from PORTUR, all diagnostic ratios reveal that the PAHs in the sediment from this sampling site are of pyrolytic origin, indicating that the intensive cultivation of sugarcane in the area and the consequent burning of sugarcane straw, can be responsible for PAH contamination.

In RTURARG, for both samples, the Phe/Ant and Ant/ (Ant+Phe) ratios indicated PAHs derived from petrogenic sources, which was unexpected because this region is primarily agricultural. These petrogenic sources may be related to local contamination events. However, the Flt/ (Flt + Py) and LMW/HMW ratios indicated the presence of PAHs from pyrolytic origins.

In RGRANDE, for sediment collected in February 2010, the Phe/Ant, Ant/(Ant+Phe), and Flt/(Flt+Py) diagnostic ratios indicated PAHs of pyrolytic origin, likely due to the burning of biomass (such as sugarcane straw), but the LMW/HMW ratio indicated the presence of PAHs from petrogenic origins. However, in July, the PAHs from this region were of petrogenic origin, according to the Phe/Ant, Ant/(Ant+Phe) and LMW/HMW ratios, but the Flt/(Flt + Py) ratio indicated the presence of PAHs from pyrolytic origins.

Diagnostic ratios have also been applied to estimate the origin of PAHs from sediment cores, and the values of these ratios are shown in Fig. 7.

In sediment collected at CAPRP in February 2010, the Phe/Ant and Ant/(Ant+Phe) ratios indicated that PAHs in the sediment core are predominantly of petrogenic origin. Flt/(Flt+Py) ratios higher than 0.5 are characteristic of wood, coal and grass combustion, and LMW/HMW ratios
Table 2 Values of phenanthrene/anthracene (Phe/Ant), anthracene/ (anthracene+ phenanthrene) (Ant/ (Ant+Phe)), fluoranthene/ (fluoranthene+ pyrene) (Flt/(Flt+Py)), and lowmolecular weight/high molecular weight (LMW/HMW) ratios for surface sediment samples from five sites collected in February and July 2010

\begin{tabular}{|c|c|c|c|c|}
\hline Location/period & $\begin{array}{l}\text { Phe/Ant ratio } \\
<10 \text { - pyrolytic } \\
>10 \text { - petrogenic }\end{array}$ & $\begin{array}{l}\text { Ant/(Ant }+ \text { Phe }) \text { ratio } \\
>0.1 \text { - pyrolytic } \\
<0.1 \text { - petrogenic }\end{array}$ & $\begin{array}{l}\text { Flt } /(\mathrm{Flt}+\mathrm{Py}) \text { ratio } \\
>0.5-\text { coal combustion } \\
>0.4 e<0.5 \text { - liquid } \\
\text { fossil fuel combustion } \\
<0.4 \text { petrogenic }\end{array}$ & $\begin{array}{l}\text { LMW/HMW } \\
<1-\text { pyrolytic }\end{array}$ \\
\hline NRP_Feb. 2010 & 17.10 & 0.06 & 0.70 & 1.01 \\
\hline CAPRP_Feb. 2010 & 9.80 & 0.09 & 0.80 & 0.52 \\
\hline PORTUR_Feb 2010 & 9.40 & 0.10 & 0.94 & 0.95 \\
\hline RTURARG_Feb 2010 & 20.87 & 0.05 & 0.55 & 0.64 \\
\hline RGRANDE-Feb 2010 & 8.45 & 0.11 & 0.70 & 2.89 \\
\hline NRP_July 2010 & 17.08 & 0.06 & 0.70 & 1.02 \\
\hline CAPRP_Jul 2010 & 12.13 & 0.08 & 0.83 & 0.72 \\
\hline PORTUR_July 2010 & 9.40 & 0.10 & 0.93 & 0.94 \\
\hline RTURARG_July 2010 & 15.16 & 0.06 & 0.74 & 0.41 \\
\hline RGRANDE-Jul. 2010 & 10.08 & 0.09 & 0.74 & 4.66 \\
\hline
\end{tabular}


Fig. 7 Values of phenanthrene/ anthracene (Phe/Ant), anthracene/ (anthracene+ phenanthrene) (Ant/ (Ant+Phe)), fluoranthene/ (fluoranthene+ pyrene) (Flt/(Flt+ Py)), and low-molecular weight/ high molecular weight (LMW/ HMW) ratios in sediment cores collected at CAPRP, RGRANDE, and RTURARG sites in February 2010 and July 2010

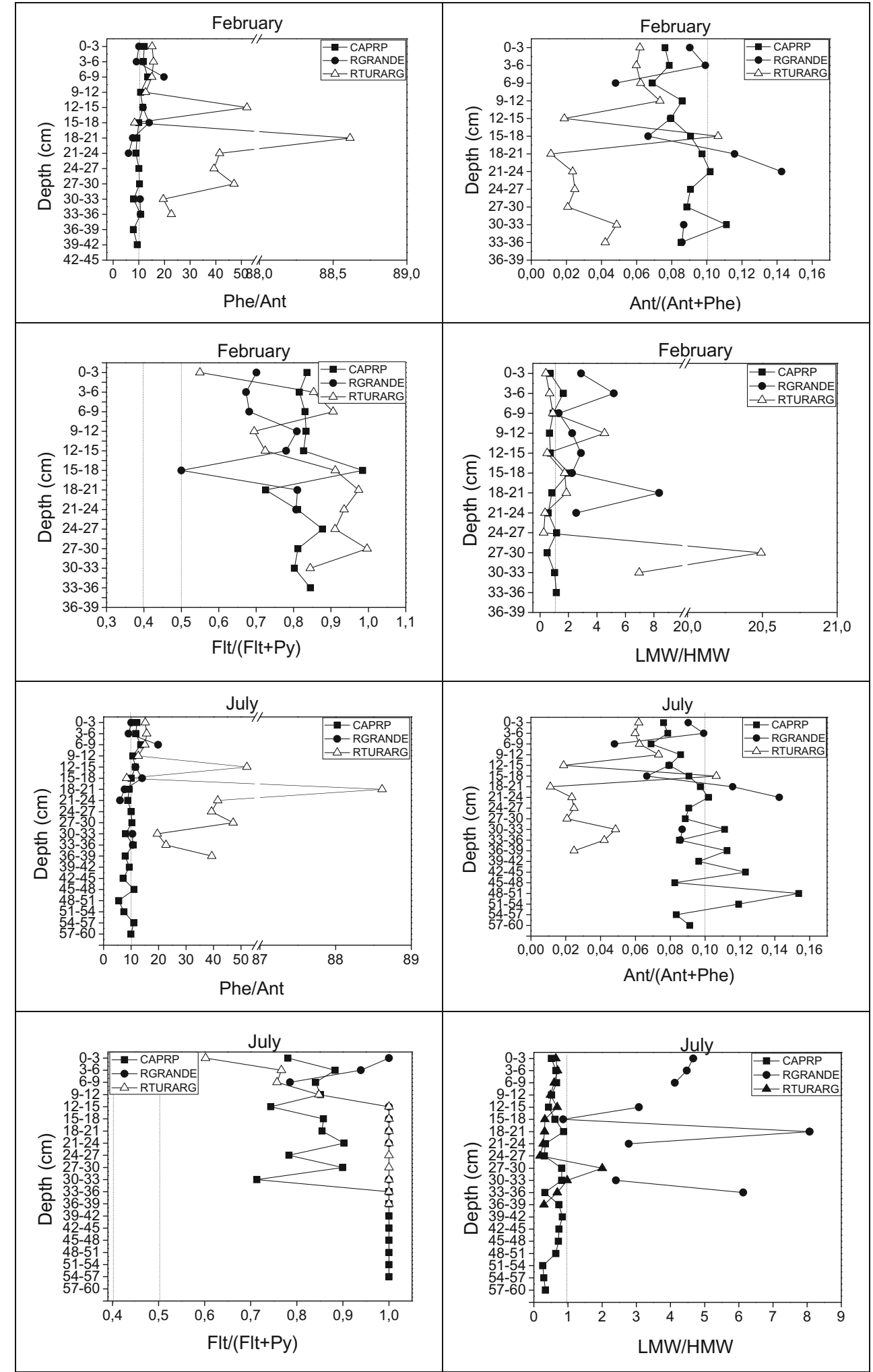

indicate pyrolytic and petrogenic contamination. In collections from July 2010, the Phe/Ant and Ant/(Ant+Phe) ratios indicated PAHs from both sources and primarily indicated PAHs of petrogenic origin in the early layers, depending on the depth of the analyzed sediment. The Flt/ $(\mathrm{Flt}+\mathrm{Py})$ ratios indicated PAHs from wood, coal, and grass combustion, and the LMW/HMW ratios indicated pyrolytic contamination. 
The samples from RTURARG were analyzed for Phe/Ant and Ant $/($ Ant + Phe) ratios and were found to contain PAHs that were primarily of petrogenic origin. The Flt/(Flt+Py) ratios indicated predominantly PAHs from wood, coal, and grass combustion, and the LMW/HMW ratios indicated pyrolytic and petrogenic contamination.

In sediment collected at RGRANDE in February 2010, the Phe/Ant and Ant/(Ant+Phe) ratios indicate that the PAHs are of pyrolytic origin down to $15 \mathrm{~cm}$, and they are of petrogenic origin below this depth. The Flt/(Flt + Py) ratios indicated PAHs from wood, coal and grass, and the LMW/HMW ratios indicated petrogenic contamination. In sediment collected in July 2010, the Phe/Ant and Ant/(Ant+Phe) ratios indicated that PAHs in upper layers are petrogenic in origin, and PAHs in deeper layers are pyrolytic in origin. The Flt/(Flt $+\mathrm{Py}$ ) ratios indicated PAH from wood, coal and grass, and the LMW/ HMW ratios indicated petrogenic contamination.

\section{Conclusions}

In general, for all sampling sites and all PAHs, the concentrations decreased with increasing sediment core depth. CAPRP, which had the most human activity, had the highest total concentration of PAHs and was the only area in which the concentration of naphthalene in surface sediment was at a higher concentration than the PEL value set by the Canadian environmental agency.

The total concentrations of the 15 PAHs found in sediment at the sites tested followed the order of CAPRP $>$ RTURARG $>$ RGRANDE. The site with the highest concentration is in a region with high vehicle traffic that is prone to contamination by runoff and atmospheric deposition. RTUARG is an area of intense sugarcane cultivation that also receives PAHs from the burning of sugarcane straw.

The diagnostic ratios used indicate that sediment from areas with robust sugarcane cultivation had pyrolytic sources of PAH, indicating the contribution of sugarcane straw burning to PAH emissions in those areas and to sediment from these regions.

Acknowledgments The authors thank the Foundation for Research Support of the State of São Paulo (FAPESP) (Projects 05/51242-8 e 10/ 09271-9) and scholarship (09/06814-4).

\section{References}

Almeida FV, Centeno AJ, Bisinoti MC, Jardim WF (2007) Persistent toxic substances (PTS) in Brazil. Quim Nov. 30:1976-1985

Andrade SJ, Silva JCFS, Zocolo GJ, Marchi MRR (2010) Contribution of sugar-cane harvesting season to atmospheric contamination by polycyclic aromatic hydrocarbons (PAHs) in Araraquara city, Southeast Brazil. Atmos Environ 44:2913-2919
ANVISA - Agência Nacional de Vigilância Sanitária. Resolução. Guia para validação de métodos analíticos e bioanalíticos, $R E \mathrm{n}^{\circ} 899$, de 29 de maio de 2003

Associação Brasileira de Normas Técnicas-ABNT, NBR 9898: preservação e técnicas de amostragem de efluentes líquidos e corpos receptores, 1987

Belin S, Sany T, Hashim R, Salleh A, Safari O, Mehdinia A, Rezayi M (2014) Risk assessment of polycyclic aromatic hydrocarbons in the West Port semi-enclosed basin (Malaysia). Environ Earth Sci 71: 4319-4332

Budzinski H, Jones I, Bellocq J, Piérard C, Garrigues P (1997) Evaluation of sediment contamination by polycyclic aromatic hydrocarbons in the Gironde estuary. Mar Chem 58:85-97

Campanha MB, Romera JP, Coelho J, Pereira-Filho ER, Moreira AB, Bisinoti MC (2014) Use of chemometric tools to determine the source of metals in sediments of the rivers of the Turvo/Grande Hydrographical Watershed, São Paulo State, Brazil. J Braz Chem Soc 25:665-674

CBH-TG-Turvo/Grande Drainage Basin Committee (2010) Available at http://www.comitetg.com.br/tg/index.php/apresentacao. Accessed 3 August 2015

CCME - Canadian Council of Ministers of the Environment (2002) Canadian sediment quality guidelines for the protection of aquatic life. Summary tables

Cheng H, Deng Z, Chakraborty P, Liu D, Ruijie Z, Xu Y, Luo C, Zhang G, Li J (2013) A comparison study of atmospheric polycyclic aromatic hydrocarbons in three Indian cities using PUF disk passive air samplers. Atmos Environ 73:16-21

Chiou CT (2002) Partition and adsorption of organic contaminants in environmental systems. John Wiley, Hoboken

Conab (2015) Companhia Nacional de Abastecimento. Acompanhamento de safra brasileira: cana-de-açúcar, safra 2015/ 2016, primeiro levantamento, abril 2015. Brasília. Available in: http://www.conab.gov.br/OlalaCMS/uploads/arquivos/15 $04 \quad 13$ 09_39_02_boletim_cana_portugues_-_10_lev_-_15-16.pdf Accesssed 18 May 2015

Cristale J, Silva FS, Zocolo GJ, Marchi MRR (2012) Influence of sugarcane burning on indoor/outdoor PAH air pollution in Brazil. Environ Pollut 169:210-216

Denis EH, Toney JL, Tarozo R, Anderson RS, Roach LD, Yongsong H (2012) Polycyclic aromatic hydrocarbons (PAHs) in lake sediments record historic fire events: Validation using HPLC-fluorescence detection. Org Geochem 45:7-17

Doong R, Linn YT (2004) Characterization and distribution of polycyclic aromatic hydrocarbon contaminations in surface sediment and water from Gao-ping River, Taiwan. Water Res 38:1733-1744

El-Mufleh A, Bechet B, Grasset L, Rodier C, Gaudin A, Ruban V (2013) Distribution of PAH residues in humic and mineral fractions of sediments from stormwater infiltration basins. J Soils Sediments 13:531-542

Fernandes MB, Sicre MA, Boireau A, Tronczynski J (1997) Polyaromatic hidrocarbon $(\mathrm{PAH})$ distribution in the Seine River and its estuary. Mar Pollut Bull 34:857-867

Fukushima T, Watanabe S, Kamiya K, Ozaki N (2012) Vertical distributions of PAHs in the sediments of four lakes in Japan. J Soils Sediments 12:1530-1540

Gebara SS, Ré Poppi N, Nascimento ALCS, Raposo Junior JR (2013) Métodos para análises de HPA e BTEX em águas subterrâneas de postos de revenda de combustíveis: um estudo de caso em Campo Grande, MS, Brasil. Quim Nov. 36:1030-1037

Gogou A, Bouloubassi I, Stephanou EG (2000) Marine organic geochemistry of the Eastern Mediterranean: 1. Aliphatic and polyaromatic hydrocarbons in Cretan Sea surficial sediments. Mar Chem 68:265-282

Han YM, Wei C, Bandowe BAM, Wilcke W, Cao JJ, Xu BQ, Gao SP, Tie XX, Li GH, Jin ZD (2015) Elemental carbon and polycyclic aromatic compounds in a 150-year sediment core from Lake Qinghai, 
Tibetan Plateau, China: influence of regional and local sources and transport pathways. Environ Sci Technol 49:4176-4183

Haritash A, Kaushik C (2009) Biodegradation aspects of polycyclic aromatic hydrocarbons (PAHs): a review. J Hazard Mater 169:1-15

IBGE - Instituto Brasileiro de Geografia e Estatística (2015). Mapa de solos do Brasil. Available in: http://www.ibge.gov.br/home Accesssed 04 Aug 2015

INMETRO - Instituto nacional de metrologia, normalização e qualidade industrial (2003) Orientação sobre validação de métodos analíticos, DOQ-CGCRE-008

Karichkhoff SW (1981) Semi-empirical estimation of sorption of hydrophobic pollutants in natural sediments and soils. Chemosphere 10: 833-846

Lin T, Qin Y, Zheng B, Li Y, Chen Y, Guo Z (2013) Source apportionment of polycyclic aromatic hydrocarbons in the Dahuofang reservoir, northeast China. Environ Monit Assess 185:945-953

Liu M, Baugh PJ, Hutchinson SM, Yu L, Xu S (2000) Historical record and sources of polycyclic aromatic hydrocarbons in core sediments from the Yangtze estuary, China. Environ Pollut 110:357-365

Lopes WA, Andrade JB (1996) Fontes, formação, reatividade e quantificação de hidrocarbonetos policíclicos aromáticos (HPA) na atmosfera. Quim Nov. 19:497-516

Lors C, Ryngaert A, Périé F, Diels L, Damidot D (2010) Evolution of bacterial community during bioremediation of PAHs in a coal tar contaminated soil. Chemosphere 81:1263-1271

Luo X-J, Chen S-J, Mai B-X, Sheng G-Y, Fu J-M, Zeng EY (2008) Distribution, source apportionment, and transport of PAHs in sediments from the Pearl river Delta and the northern south China sea. Arch Environ Contam Toxicol 55:11-20

Luthy RG, Aiken GR, Brusseau ML, Cunningham SD, Gschwend PM, Pignatello JJ, Reinhard M, Traina SJ, Weber WJ, Westall JC (1997) Sequestration of hydrophobic organic contaminants by geosorbents. Environ Sci Technol 31:3341-3347

Magalhães D, Bruns RE, Vasconcellos PC (2007) Hidrocarbonetos policíclicos aromáticos como traçadores da queima de cana-deaçúcar: uma abordagem estatística. Quim Nov. 30:577-581

Maioli OLG, Rodrigues KC, Knoppers BA, Azevedo DA (2010) Distribution and sources of polycyclic aromatic hydrocarbons in surface sediments from two brazilian estuarine systems. J Braz Chem Soc 21:1543-1551

Manoli E, Kouras A, Samara C (2004) Profile of analysis of ambient and source emitted particle-bound polycyclic aromatic hydrocarbons from three sites in northern Greece. Chemosphere 56:867-878

Medeiros PM, Bicego MC, Castelao RM, Del Rosso CD, Fillmann G, Zamboni AJ (2005) Natural and anthropogenic hydrocarbon inputs to sediments of Patos Lagoon estuary, Brazil. Environ Int 31:77-87

Meniconi MFG, Gabardo IT, Carneiro MER, Barbanti SM, Silva GC, Massone CG (2002) Brazilian oil spills chemical characterization-case studies. Environ Forensics 3:303-321

Nishigima FN, Weber RR, Bícego MC (2001) Aliphatic and aromatic hydrocarbons in sediments of Santos and Cananeia, SP, Brazil. Mar Pollut Bull 42:1064-1072
Prokes R, Vrana B, Komprdova K, Klanova J (2014) Annual dynamics of persistent organic pollutants in various aquatic matrices: a case study in the Morava River in Zlin district, Czech Republic. J Soils Sediments 14:1738-1752

Secretaria de Desenvolvimento e Palnejamento Social (2012) Available in: http://www.planejamento.sp.gov.br/noti_anexo/files/uam/ trabalhos/SJ\%20Rio\%20Preto.pdf Accesssed 04 Aug 2015

Shahsavari E, Adetutu EM, Anderson PA, Ball AS (2013) Necrophytoremediation of phenanthrene and pyrene in contaminated soil. J Environ Manage 122:105-112

Shen Q, Wang KY, Zhang W, Zhang SC, Wang X (2009) Characterization and sources of PAHs in an urban river system in Beijing, China. J Environ Geochem Health 31:453-462

Sho M, Hamel C, Greer CW (2004) Two distinct gene clusters encode pyrene degradation in Mycobacterium sp. strain S65. Microbiol Ecol 48:209-2020

Silva TR, Lopes SRP, Spörl G, Knoppersc BA, Azevedo DA (2013) Evaluation of anthropogenic inputs of hydrocarbons in sediment cores from a tropical Brazilian estuarine system. Microchem J 109:178-188

Soclo HH, Garrigues PH, Ewald M (2000) Origin of polycyclic aromatic hydrocarbons (PAHs) in coastal marine sediments: case studies in Cotonou (Benin) and Aquitaine (France) areas. Mar Pollut Bull 40: 387-396

Ströher GL, Ré Poppi N, Raposo JL, Gomes de Souza JB (2007) Determination of polycyclic aromatic hydrocarbons by gas chromatography-ion trap tandem mass spectrometry and source identifications by methods of diagnostic ratio in the ambient air of Campo Grande, Brazil. Microchem J 86:112-118

United States Environmental Protection Agency (US EPA)—Method 3540C. Soxhlet extraction, 1996b

United States Environmental Protection Agency (US EPA)—Method 3630C. Silica gel clean up, 1996a

Venturini N, Tommasi LR (2004) Polycyclic aromatic hydrocarbons and changes in the trophic structure of polychaete assemblages in sediments of Todos os Santos Bay, northeastern, Brazil. Mar Pollut Bull 48:97-107

Yunker MB, Macdonald RW, Goyette D, Paton DW, Fowler BR, Sullivan D, Boyd J (1999) Natural and anthropogenic inputs of hydrocarbons to the Strait of Georgia. Sci Total Environ 225:181-209

Zhang Y, Shi G-L, Guo C-S, Xu J, Tian Y-Z, Feng Y-C, Wang Y-Q (2012) Seasonal variations of concentrations, profiles and possible sources of polycyclic aromatic hydrocarbons in sediments from Taihu Lake, China. J Soils Sediments 12:933-941

Zhang L, Qin Y, Zheng B, Lin T, Li Y (2013) Polycyclic aromatic hydrocarbons in the sediments of Xiangjiang River in south-central China: occurrence and sources. Environ Earth Sci 69:119-125

Zheng TH, Ran Y, Chen LG (2014) Polycyclic aromatic hydrocarbons (PAHs) in rural soils of Dongjiang river basin: occurrence, source apportionment, and potential human health risk. J Soils Sediments $14: 110-120$ 